\title{
The Effect of Macroeconomics on Stock Price Index in the Republic of China
}

\author{
Submitted 18/03/20, $1^{\text {st }}$ revision $11 / 04 / 19,2^{\text {nd }}$ revision $28 / 05 / 19$, accepted $30 / 07 / 20$
}

\author{
Endang Mahpudin ${ }^{1}$
}

\begin{abstract}
:
Purpose: This study examines the influence of inflation, exchange rates, interest rates, and money circulation on share prices in China. The macroeconomics of a country has always impacted share prices in the stock markets, which are vital indicators often used by investors in determining the country's macroeconomic stability for investment decisions.

Design/Methodology/Approach: The study elicits descriptive quantitative analysis to determine the nature of the influence of the research variables on stock prices.

Findings: The study found that inflation and money supply affect the Stock Price Index in China, while the exchange rate and interest rate variables do not significantly impact.

Practical Implications: The pattern of influence in China is different from other research conducted in other emerging economies and developed economies. However, the differences between markets in developed countries and emerging economies, such as high volatility in the case of developing economies' markets, signal frequent macroeconomic changes.

Originality/Value: A definitive mapping of stock markets' behavior, especially in emerging economies, remains elusive despite several previous studies. This study draws attention to the importance of comparatively studying stock markets in developed and emerging economies to produce findings that can be used in the economy's macroeconomic spectrum.
\end{abstract}

Keywords: Macroeconomics, stock prices, inflation, China.

JEL Code: G20, G23, N20.

Paper Type: Research study.

\footnotetext{
${ }^{1}$ Accounting Program, Faculty of Economics and Business, Universitas Singaperbangsa Karawang, E-mail: mahpudine565@gmail.com/ endang.mahpudin@fe.unsika.ac.id
} 


\section{Introduction}

The stock price is the closing price of the stock market during the observation period for each type of stock that is sampled. Investors always observe their movements. One of the basic concepts in financial management is that the objectives to be achieved by financial management are to maximize the value of the company. For companies that have gone public, this goal can be achieved by maximizing the market value of the relevant stock prices. Thus, decision making is always based on the consideration of maximizing the wealth of the shareholders.

In emerging market countries, the volatility index is higher. Compared to the global volatility index, the emerging market volatility index is 22,53 , while the world volatility index is only 13,16. According to Kaminsky and Reinhart (1999), stock market volatility in developing countries is generally higher than in developed markets. The higher volatility of stock prices shows that the risk that must be borne by an investor is also higher because of the high uncertainty of stock prices.

Manurung and Rizky (2009) stated that shares with large capitalization have value more than Rp 1 trillion, shares with medium-capitalization have value about Rp 100 billion, while shares with small capitalization have a value below Rp 100 billion. Data obtained from MSCI related to emerging markets are the composition of the capitalization of emerging markets, namely China with $32.30 \%$, South Korea $11.48 \%$, Taiwan $11.15 \%$, India $8.6 \%$, Brazil $7.45 \%$, and other countries including Indonesia with $28.93 \%$, bearing in mind that capitalization will have an impact on the value of transactions traded on the stock exchange.

There are four characteristics of emerging market exchanges: the very low correlation with developed markets, high returns, and predictable stock returns because they are inefficient, and high volatility (Sutriawan and Haryanto, 2013). The same result was also stated by Campbell (2002) when viewed the issue from the risk and return. There are several distinctive characteristics of emerging market stocks, including high volatility, high expected returns, and low correlations between emerging markets and developed stock markets.

The relationship between macroeconomic variables and stock prices has been studied since the 1970s. Initially, the research associated with macroeconomic relationships to stock prices in developed countries, such as the United States or the European Union was conducted by Fama (1981), Mukherjee and Naka (1995), Cheung and Ng (1998), Nasseh and Strauss (2000), and Chaudhuri and Smile (2004). The results of research in developed countries such as the United Kingdom, Canada, France, Germany, and Italy show that the pattern of relationship of each macroeconomic variable is different. The exchange rate variable on stock prices was indicated as positive by Ajayi and Mougoue (1996). However, according to Ma and Kao (1990), the relationship was negative for a country with an export-dominated economy and positively affected a country with an economy dominated by imports. 
Macroeconomic factors that influence stock prices in developed countries are interest rates. Surbakti (2011) states that many investors base their investment decision considerations on financial information in the United States. The most crucial aspect to be used as a basis for investment decisions is the movement of the interest rates of the U.S. Central Bank (The Fed). McEachrn (2000) said that the Fed's interest rate is the interest rate set by the Fed against loans given to banks. Suppose there is an increase in the Fed's interest rates. In that case, it allows investors to move their funds from emerging markets back to the United States (Surbakti, 2011).

Based on these studies' results, it appears that each emerging market has differences in the macroeconomic influence with stock prices, as well as developed countries, especially with similar studies before the 2004 period. This study examines the presence or absence of the influence of inflation, exchange rates, interest rates, and the money supply to share prices in China. These results will be compared with other emerging market countries, developed countries, and research before 2004.

\section{Literature Review}

Research related to the impact of macroeconomics on stock prices has been widely studied in emerging markets, developed countries, and research in the period before 2004 (Thalassinos and Thalassinos, 2006; Thalassinos and Politis 2011). Basher, Haug, and Sadorsky (2012) postulate that macroeconomic variables consist of inflation rates, GDP growth rates, exchange rates, and money supply from directly related to stock prices in the BRICS country. Besides, research on emerging markets was also conducted by Bhattacharya et al. (2009), who examined the relationship between stock prices and macroeconomic aggregates in India from April 1990 to March 2001. They did not find a two-way causal relationship between stock prices and foreign exchange reserves, the real effective exchange rate, and the trade balance. Furthermore, researchers conducted a study related to the causal relationship between macroeconomic variables and stock prices in India from April 1991 to December 2005. The results showed that there was a direct relationship from the money supply to stock prices. Wongbangpo and Sharma (2002), who researched Indonesia, Malaysia, the Philippines, Singapore, and Thailand, discovered that money supply, interest rates, and exchange rates are influential factors. In Ghana, Coleman and Tettey (2008) stated that loan interest rates, inflation, money supply, and exchange rates are influential factors.

Ajayi and Mougoue (1996) conducted a study in 8 developed economies (Canada, France, Germany, Italy, Japan, the Netherlands, United Kingdom, and the USA) and found a two-way relationship where the increase in stock prices has a long-term positive effect on the value of the temporary domestic currency while currency depreciation has a negative long-term effect on the stock market. Thalassinos et al. (2015) have examined the European crisis and the role of credit swaps with interesting results concerning the effect of macroeconomics in their analysis. 
Fama (1981), states that macroeconomic variables such as industrial production index are positively related to stock market performance. When the industrial production index increases, stock returns will also increase. According to Mukherjee and Naka (1995), the impact on the stock market price of the macroeconomic variables investigated mainly focuses on developed countries in the West, such as the United States or the European Union.

Benaković and Posedel (2010) analyzed the rate of return of fourteen shares on the Croatian capital market by taking into account inflation, industrial production, interest rates, market indices, and oil prices. The results show that the index is positively related to stock returns and has the most considerable statistical significance for all stocks. Furthermore, interest rates, industrial production, and oil prices are positively related, while inflation is the opposite.

Research that examines the relationship between macroeconomic variables and stock prices in Emerging Stock Markets (ESMs) began after the 1980s. However, the interest in investing in emerging markets has developed rapidly over the past decade. Another research has been conducted to determine the determinants of stock price movements (Chen et al., 1986; Fama and French, 1998; Bulmash and Trivoli, 1991; Hooker, 2004; Gjerde and Sættem, 1999; Bilson, Brailsford and Hooper, 2001; Asprem, 2001; Asprem, 2001; 1989; Wasserfallen, 1989; Fama, 1981; Abdullah and Hayworth, 2013). Macroeconomic factors in Indonesia indicate that there is no single factor affecting stock prices, which shows that in Indonesia, as a developing country, there is no certainty about macroeconomic factors that affect stock prices (Mahpudin, 2020).

Based on the results of these studies, it seems that in every emerging market country, there are differences in macroeconomic influence with stock prices, as well as developed countries, especially with similar studies before the 2004 period. This study examines the presence or absence of the influence of inflation, exchange rates, interest rates, and the money supply to share prices in China. These results will be compared with other emerging market countries, developed countries, and research before 2004.

\section{Methodology}

The variables in this study consisted of independent variables and dependent variables, namely:

1. The Independent variable is a variable whose existence is not influenced by other variables. The list of independent variables in this study consisted of:
a. Currency exchange rates as variable X1
b. Interest rate as variable $\mathrm{X} 2$
c. The amount of money in circulation as variable X3
d. Inflation as variable $\mathrm{X} 4$ 
2. The dependent variable is a variable whose existence is not free to be influenced by other variables. The dependent variable in this study is the Stock Price denoted as Y. Secondary data used was already available before it was obtained from other parties, collected from various documents, literature, articles, and scientific papers that have been confirmed as correct. Secondary data is used to consider that this data has validity guaranteed by other parties so that it is suitable for use in this research. Data collected include exchange rates, interest rates, money in circulation, and inflation in China in 2004-2018. Data sources included:

a. Share prices are taken from the monthly data at the end of the closing period of the Shanghai Stock Exchange.

b. Macroeconomic variables are drawn from monthly data of the Central Bank of China.

Data analysis uses descriptive quantitative research results to examine the impact, then analyzed descriptively with comparisons to developed countries, emerging markets, and similar studies before the 2004 period.

\section{Results and Discussion}

The results showed the effect of variables $\mathrm{X}$ and $\mathrm{Y}$, that is to say; the interest rates did not significantly affect the stock price index, the exchange rate did not significantly affect the stock price index, inflation significantly impacted the stock price index and the amount of money circulating significantly affected the price index. This means that the inflation variable and the money supply affect the Stock Price Index in China. In contrast, the exchange rate and interest variables do not significantly affect it.

The results of these studies have differences with the research conducted by Pal and Mittal (2011) in India during 1995-2008, some of the several variables that allegedly affected emerging market stock prices turned out to be significant (inflation, interest rates, and exchange rates) and some, not significant (the amount of money in circulation).

It has a difference with India as an emerging market country. However, this study also shows a difference in research in developed countries. Mads Asprem (1989) researched in France, Germany, Italy, Switzerland, and the U.K., the period 19681984, and stated that the macro factors that shape stock prices include inflation, with a negative effect, interest rates with a negative effect, the exchange rate with a positive effect. In contrast, employment and imports thave no influence on stock prices. Ratanapakorn and Sharma (2007) in a study conducted in the USA from 1975 to 1999 . This study concluded that stock prices formed by money supply, inflation, exchange rates, industrial production, and interest rates positively affect stock prices. 
Research conducted on the Thai Stock Exchange by Sardar MN Islam et al. (2004) concluded that interest rates determine market indices, bond interest rates, foreign exchange rates, market capitalization, price to income ratios, and consumer price indices, both in the short- and long-term markets. Halil Tunalı (2011) investigated the relationship between macroeconomic variables and stock returns on the Turkish stock market using the theoretical framework of Arbitration Pricing. The study concludes that there is a long-term relationship between the Turkish economy's fundamental macroeconomic indicators and stock returns at different levels.

Bilson et al. (2001) examined the ability of local macroeconomic variables (money supply, prices of goods, and physical activities) in explaining stock returns in 20 developing country exchanges for the period 1985-1997. The results point to the most obvious variable, the exchange rate variable. Macroeconomic variables affect the macro level, and the money supply has greater importance. A long-term relationship with macroeconomic variables, stock prices and money supply, CPI, IPI, and foreign exchange rates as explanatory variables using the Pakistan 100 stock market price index from 1974 to 2004 . The results show that there is a causal relationship between stock prices and macroeconomic variables.

Research examining the relationship between macroeconomic variables and stock prices in Emerging Stock Markets (ESMs) began after the 1980s. However, interest in investments in emerging markets has developed rapidly over the past decade. Other research has been conducted to establish the determinants of stock price movements (Chen et al., 1986; Fama and French, 1998; Bulmash and Trivoli, 1991; Hooker, 2004; Gjerde and Sættem, 1999; Bilson, Brailsford and Hooper, 2001; Asprem, 2001; Asprem, 2001; 1989; Wasserfallen, 1989; Fama, 1981; Abdullah and Hayworth, 2013). All research used illustrates that there is a strong relationship between macroeconomic variables and stock prices in emerging market countries.

Chen, Kim, and Kim (2005) conducted research in Taiwan from 1989-2003 and found that the macro factors that formed share prices, namely, interest rates, had a negative effect. The money supply had a positive effect. Likewise, unemployment impacts stock prices, while the monetary policy does not affect stock prices. Adrangi, Chatrath, and Sanvicente (1998) researched Brazil in the 1986-1997 period and stated that the macro factors that shape stock prices, namely inflation, have a negative effect. Likewise, real economic activity influences stock prices.

Flannery and Protopapadakis (2002), in their research conducted in the United Kingdom, Switzerland, Belgium, and the United States, in 1980-1996 and discovered that the macro factors that makeup stock prices are negative inflation and positive money supply. Gan, Yong, and Zhang (2006) researched in New Zealand in the period 1990-2003 and found out that the macro factors that makeup stock prices are: inflation, with a negative effect, interest rates with a negative effect, the exchange rate has a positive effect. Likewise, the real gross domestic product affects stock prices. Gjerdea and Saettem (1999) conducted a study in Norway between 
1974-1994 and stated that the macro factors that shape stock prices, namely interest rates, have a negative effect. So do, oil price changes and domestic production influence stock prices. From the research referred to, in developed countries, stock prices are affected by inflation, which has a negative effect, interest rate- that has a negative and positive effect, a favorable exchange rate, and a positive money supply.

In general, the results of this study differ from the results of other studies investigating the relationship between macroeconomic variables and stock prices. There is a significant relationship between macroeconomic variables and stock prices as did Bilson et al. (2001), in the countries of Argentina, Brazil, Chile, Colombia, Mexico and Venezuela, India, Indonesia, Malaysia, Pakistan, the Philippines, South Korea, Taiwan, Thailand, Greece, Portugal, Turkey, Jordan, Nigeria, Zimbabwe in the period, 1985 to 1997, Maysami et al. (2005) in Singapore for the period 1989 to 2001, Coleman and Tettey (2008) in the country of Ghana, for the period 1991 to 2005, Wongbangpo and Sharma (2002) in Indonesia, Malaysia, the Philippines, Singapore, and Thailand, for the period 1985 to 1996.

From the research, the macroeconomic determinant factors influencing stock prices consist of inflation, interest rates, and exchange rates, which are variables that can directly affect the rise and fall of emerging market stock prices. However, these results differ from other studies in China, showing that inflation and the money supply affect the Stock Price Index in China. At the same time, the exchange rate and interest rate variables have no significant effect.

\section{Conclusion}

The research results obtained indicate that inflation and money supply affect the Stock Price Index in China. At the same time, the exchange rate and interest rate variables do not have a significant impact. The pattern of influence in China has a difference with researches in other emerging market countries, developed countries, and researches in the period before 2004. Thus, emerging market countries have differences in macroeconomic influences (inflation, interest rates, exchange rates, and money supply) with share prices, as well as in research in developed countries and the results of research conducted before 2004.

\section{References:}

Abdullah, D.A., Hayworth, S.C. 2013. Administration Macroeconometrics of Stock Price Fluctuations. Journal of Business and Economics, 32(1), 50-67.

Adrangi, B., Chatrath, A., Sanvicente, A.Z. 1998. Inflation, Output, and Stock Prices:

Evidence from Brazil. The Journal of Applied Business Research, 18(1), 61-77.

Ajayi, R.A., Mougoue, M. 1996. On the Dynamic Relationship Between Stock Prices and

Exchange Rates. The Journal of Financial Research, XIX(2), 193-207.

Asprem, M. 1989. Stock prices, asset portfolios and macroeconomic variables in ten

European countries. Journal of Banking and Finance, 13(4-5), 589-612. 
Basher, S.A., Haug, A.A., Sadorsky, P. 2012. Oil prices, exchange rates and emerging stock markets. Energy Economics, 34(1), 227-240.

Benakovic, D., Posedel, P. 2010. Do macroeconomic factors matter for stock returns? Evidence from estimating a multifactor model on the Croatian market. Business Systems Research, 1(1-2), 1-13.

Bhattacharya, C.B., Korschun, D., Sen, S. 2009. Strengthening stakeholder-company relationships through mutually beneficial corporate social responsibility initiatives. Journal of Business ethics, 85(2), 257-272.

Bilson, C.M., Brailsford, T.J, Hooper, V.J. 2001. Selecting macroeconomic variables as explanatory factors of emerging stock market returns. Pacific Basin Finance Journal, 9(4), 401-426.

Bulmash, S.B., Trivoli, G.W. 1991. Time-Lagged Interactions Between Stock Prices and Selected Economic Variables. The Journal of Portfolio Management, 17(4), 61-67.

Campbell, J.Y. 1996. Understanding risk and return. Journal of Political economy, 104(2), 298-345.

Chaudhuri, K., Smiles, S. 2004. Stock market and aggregate economic activity: Evidence from Australia. Applied Financial Economics, 14(2), 121-129.

Chen, M.H., Kim, W.G., Kim, H.J. 2005. The impact of macroeconomic and nonmacroeconomic forces on hotel stock returns. International Journal of Hospitality Management, 24(2), 243-258.

Chen, N.F., Roll, R., Ross, S.A. 1986. Economic Forces and the Stock Market Economic Forces and the Stock Market. The Journal of Business, 5921236(3), 383-403.

Cheung, Y.W., Ng, L.K. 1998. International evidence on the stock market and aggregate economic activity. Journal of empirical finance, 5(3), 281-296.

Coleman, A.K., Tettey, K.A. 2008. Pasar Uang dan Pasar Valuta Asing. Jakarta, Salemba Empat.

Fama, E.F. 1981. Stock Returns, Real Activity, Inflation, and Money. American Economic Association Stock Returns. The American Economic Review, 71(4), 545-565.

Fama, E.F., French, K.R. 1998. Eugene's Taxes, Financing Decisions, and Firm Value. The Journal of Finance, 53(3), 819-843.

Flannery, M.J., Protopapadakis, A.A. 2002. Macroeconomic factors do influence aggregate stock returns. Review of Financial Studies, 15, 751-782.

Gan, C., Lee, M., Hwa, H., Yong, A., Zhang, J. 2006. Macroeconomic Variables and Stock Market Interactions: New Zealand Evidence. Investment Management and Financial Innovations, 3(4), 89-101.

Gjerde, O., Saettem, F. 1999. Causal relations among stock returns and macroeconomic variables in a small, open economy. Journal of International Financial Markets, Institutions and Money, 9(1042), 61-74.

Hooker, M.A. 2004. Macroeconomic factors and emerging market equity returns: A Bayesian model selection approach. Emerging Markets Review, 5(4), 379-387.

Kaminsky, G.L., Reinhart, C.M. 1999. The twin crises: the causes of banking and balance-ofpayments problems. American economic review, 89(3), 473-500.

Ma, C.K., Kao, G.W. 1990. On Exchange Rate Changes and Stock Price Reactions. Journal of Business Finance and Accounting, 17(3), 441-449.

Mahpudin, E. 2020. Pengaruh Faktor Makroekonomi Terhadap Harga Saham Di Negara Emerging Market. Doctoral dissertation, Universitas Pendidikan Indonesia.

Manurung, A.H., Rizky, L.T. 2009. Successful Financial Planner: A Complete Guide. Jakarta, Grasindo. 
Maysami, R.C., Howe, L.C., Rahmat, M.A. 2005. Relationship between macroeconomic variables and stock market indices: Cointegration evidence from stock exchange of Singapore's all-S sector Indices. Journal of Management, 24.

McEachrn, W.A. 2000. Macroeconomics: Contemporary Approach, Issue 1. Translated by Sigit Triandaru Jakarta, Salemba.

Mukherjee, T.K., Naka, A. 1995. Dynamic relationship between macroeconomic variables and the Japnese stock market an application of a vector error correction model. Journal of Financial Research, 18(2), 223-237.

Nasseh, A., Strauss, J. 2000. Stock prices and domestic and international macroeconomic activity: a cointegration approach. The Quarterly Review of Economics and Finance, 40(2), 229-245.

Pal, K., Mittal, R. 2011. Impact of macroeconomic indicators on Indian capital markets. The journal of risk finance, 12(2), 84-97.

Ratanapakorn, O., Sharma, S.C. 2007. Dynamic analysis between the U.S. stock returns and the macroeconomic variables. Applied Financial Economics, 17(5), 369-377.

Sardar, M.N. 2008. Corporate Government and Firm Value, First Edition. Wagon Lane, Bigley BD16 WA. UK, Emerald Group.

Surbakti, Edhy Priyatna Anugrah. 2011. Pengaruh Non Farm Payroll, suku bunga bank sentral Amerika Serikat (The Fed), dan Indeks Nikkei 225 terhadap Indeks dari sahamsaham perusahaan berbasisi Syariah di Jakarta Islamic Index. Jurnal Akuntansi, 3(1), 34-52.

Sutriawan, A., Haryanto, A.M. 2013. Analisis Faktor-Faktor Yang Mempengaruhi Harga Saham Perusahaan Manufaktur Di Bei Tahun 2010-2012. Doctoral dissertation, Fakultas Ekonomika dan Bisnis.

Thalassinos, I.E., Thalassinos, E.P. 2006. Stock Markets' Integration Analysis. European Research Studies Journal, 9(3-4), 3-14.

Thalassinos, I.E. and Politis, D.E. 2011. International Stock Markets: A Co-integration Analysis. European Research Studies Journal, 14(4), 113-129.

Thalassinos, I.E., Stamatopoulos, D.T. and Thalassinos, E.P. 2015. The European Sovereign Debt Crisis and the Role of Credit Swaps. Chapter book in The WSPC Handbook of Futures Markets (eds) W. T. Ziemba and A.G. Malliaris, in memory of Late Milton Miller (Nobel 1990) World Scientific Handbook in Financial Economic Series Vol. 5, Chapter 20, pp. 605-639. DOI: 10.1142/9789814566926_0020.

Tunali, H. 2011. Systematic Mortgage: Temelleri, Gelişimi Ve Krizi. İktisat Fakültesi Mecmuas1.

Wasserfallen, W. 1989. Macroeconomics news and the stock market. Evidence from Europe. Journal of Banking and Finance, 13(4-5), 613-626.

Wongbangpo, P., Sharma, S.C. 2002. Stock market and macroeconomic fundamental dynamic interactions: ASEAN-5 countries. Journal of Asian Economics, 13(1), 27-51. 